\title{
溶出処理中の多孔質ガラスの割れ
}

\author{
森 本 繁樹・J.D. Mackenzie* \\ セントラル硝子 (株) テクニカルセンター, 515 松阪市大口町 1510 \\ * Department of Materials Science and Engineering, University of California \\ at Los Angeles, Los Angeles, CA 90024, U. S. A.
}

\section{Cracking of Porous Glass during Leaching}

\author{
Shigeki MORIMOTO and J. D. MACKENZIE* \\ Technical Center, Central Glass Co., Ltd., 1510, Ooguchi-cho, Matsusaka-shi, Mie 515
* Department of Materials Science and Engineering, University of California at Los Angeles,
Los Angeles, CA 90024 , U. S. A.
}

Factors affecting cracking of porous glasses during leaching have been confirmed experimentally for two different composition glasses under leaching condition in which only leached or unleached layer shows cracking. When a glass exhibits swelling during leaching, cracks are developed in the unleached layer due to the generation of tensile stress in it. In contrast, when a glass shows shrinkage, the tensile stress generated in leached layer leads to cracking of this layer. To reduce this tensile stress, it is assumed to be very important that $\mathrm{Na}_{2} \mathrm{O}$ in the $\mathrm{SiO}_{2}$-rich phase is not be extracted and that $\mathrm{SiO}_{2}$-gels in pores are removed. Experimental results showed that $\mathrm{H}_{2} \mathrm{O}$-leaching satisfies these requirements even for glasses which showed cracking due to swelling or shrinkage during typical acid leaching. In fact, a large amount of $\mathrm{SiO}_{2}$-gels did not stay in pores and $\mathrm{Na}_{2} \mathrm{O}$ was not extracted by $\mathrm{H}_{2} \mathrm{O}$ leaching. It was noticed, however, that in further leaching with acid solution sometimes cracks developed in leached layer, depending on the glass compositions and heating conditions.

[Received February 28, 1990: Accepted May 24, 1990]

Key-words : Porous glass, Acid leaching, Cracking, Leached layer, Unleached layer, Stress

\section{1. 緒言}

多孔質ガラスは，通常，分相したアルカリホウケイ酸 ガラスを酸溶出することによって得られる゙!。しかしな がら，基礎ガラ又組成，熱処理条件あるいは酸溶出条件 によっては，ガラスは溶出過程でしばしば伸縮を示し ${ }^{2 !}$, その結果生じるひずみが多孔質ガラスの割机の原因之 なっている。

従来より，多孔質ガラスの割れの原因及びそれを防ぐ 方法については，種々検討されている11 61。Corning 社 のHood ら”は，割れの生じない最適組成域を見いだし， この組成域内では伸縮が生じず，したがって割れも発生 しないと報告している。また，適当量の $\mathrm{Al}_{2} \mathrm{O}_{3}$ は，割れ を防ぐのに効果的であるとしている。最近，江口ら゙は， 酸溶出中のガラスの伸縮を直接測定し，ガラス組成と伸 縮の関係を明らかにした。それによれば，酸溶出時の伸 縮を決定するのは，熱処理条件はもちろんであるが，ガ ラス中の $\mathrm{Na}_{2} \mathrm{O} / \mathrm{Na}_{2} \mathrm{O}+\mathrm{B}_{2} \mathrm{O}_{3}$ 比であり，この比が 0.167 〜0.286の領域では，ほぼ一定の膨張量を示すが，比が 0.286 を越えると急激に収縮に転じ，極めて割れやすく なるとしている。更に，約 $3.5 \mathrm{wt} \%$ の $\mathrm{Al}_{2} \mathrm{O}_{3}$ を導入す ることにより，ガラスは伸縮を示さなくなり，割れなく
なると報告している。

一方，Volf ${ }^{3 !}$ 及び Takamori ら ${ }^{4}$ は，このような伸縮 の生じる原因を検討し，膨張は多孔質ガラスの細孔中に 残留している $\mathrm{SiO}_{2}$ ゲルの水和によって生じ，残留 $\mathrm{SiO}_{2}$ ゲルの量によって膨張量が変化することを報告してい る。また，収縮については, Drexhage ら $ら^{51 \cdot 61}$ は, $\mathrm{SiO}_{2} リ ッ$ チ相中から $\mathrm{Na}_{2} \mathrm{O}$ が抽出されることにより収縮が生じ， 江口 ${ }^{71}$ も， $\mathrm{Na}_{2} \mathrm{O} / \mathrm{Na}_{2} \mathrm{O}+\mathrm{B}_{2} \mathrm{O}_{3}$ 比が 0.286 以上で急激に 収縮に転じるのは，この組成域で $\mathrm{SiO}_{2}$ リッチ相中に多 量の $\mathrm{Na}_{2} \mathrm{O}$ が含まれるようになり，この $\mathrm{Na}_{2} \mathrm{O}$ が抽出さ れるためであるうと結論している。

以上の文献に示された実験結果から，著者らは溶出時 の割れについて次のような仮説を得た。すなわち， $\mathrm{SiO}_{2}$ リッチ相からの $\mathrm{Na}_{2} \mathrm{O}$ の抽出がなく，かつ $\mathrm{SiO}_{2}$ ゲ ルが残留しないように溶出することによって，割れのな い多孔質ガラスが得られると考えた。本実験では，典型 的な酸溶出では割れが発生するようなガラス組成と熱処 理条件を選び，これらに割れが発生しない溶出条件を検 討し，上記の仮説が成立することを証明し，更に，従来 提出されている伸縮の原因を検証することを目的とし た。 


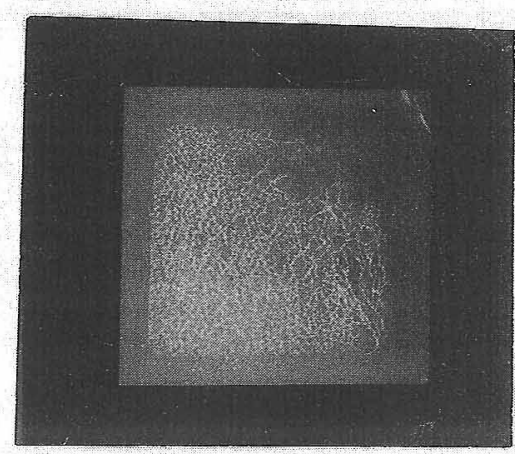

No.1 Glass

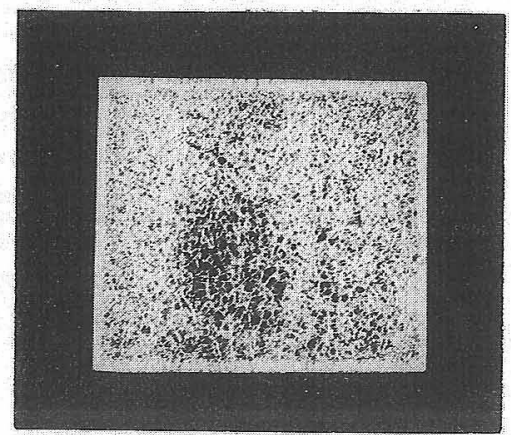

No. 2 Glass

Fig. 1. Cracking of porous glasses during acid leaching. No. 1 glass; Cracks in unleached layer. No. 2 glass; Cracks in leached layer.

Table 1. Analyzed glass compositions (wt \%) studied.

\begin{tabular}{c|cccc|c}
\hline No. & Si02 & A1203 & B203 & Na20 & N* \\
\hline 1 & 45.1 & 1.64 & 43.6 & 9.61 & 0.182 \\
2 & 44.2 & 3.21 & 43.3 & 9.38 & 0.162 \\
\hline \multicolumn{7}{r}{ N*: (Na20-A1203)/(Na20-A1203*B203) }
\end{tabular}

\section{2. 实験方法}

\section{1 ガラス試料の調製}

使用したガラスの分析組成を表 1 に示す。これらのガ ラスは， $\mathrm{B}_{2} \mathrm{O}_{3}$ 及び $\mathrm{Na}_{2} \mathrm{O}$ 量が一定で $\mathrm{SiO}_{2}$ の一部をそれ ぞれ 1 及び $2 \mathrm{~mol} \%$ の $\mathrm{Al}_{2} \mathrm{O}_{3}$ で置換したものであり，熱 水による溶出が可能である ${ }^{81}$.

$100 \mathrm{~g}$ のガラスに相当する原料混合物を $50 \mathrm{cc}$ の白金 るつぼに入れ，電気炉中で $1250^{\circ} \mathrm{C} て ゙ 3$ 時間溶融し，鉄 板上に流し出した。これより小片を切り出し，いずれの ガラスも $520^{\circ} \mathrm{C} て ゙ 24$ 時間熱処理して分相させた。炉か ら取り出して空気中で放泠した後, 約 $0.3 \times 2 \times 3 \mathrm{~cm}$ の 大きさに仕上げ，溶出実験に供した。

\section{2 溶出实験}

3 種類の溶出条件を以下に示す。なお，(c) 条件は， 熱水溶出後更に酸溶出するものである.

(a) $0.25 \mathrm{~N}_{-} \mathrm{H}_{2} \mathrm{SO}_{4}$, Acid (cc)/Glass (g) =200, 95 ${ }^{\circ} \mathrm{C}-24 \mathrm{~h}$.

(b) $\mathrm{H}_{2} \mathrm{O}, \mathrm{H}_{2} \mathrm{O}(\mathrm{cc}) / \mathrm{Glass}(\mathrm{g})=200,95^{\circ} \mathrm{C}-24 \mathrm{~h}$.

(c) $\mathrm{H}_{2} \mathrm{O}, \mathrm{H}_{2} \mathrm{O}(\mathrm{cc}) / \mathrm{Glass}(\mathrm{g})=200,95^{\circ} \mathrm{C}-24 \mathrm{~h}$ followed by $2 \mathrm{~N}-\mathrm{H}_{2} \mathrm{SO}_{4}$, Acid (cc)/Glass $(\mathrm{g})=40,95^{\circ} \mathrm{C}$ $24 \mathrm{~h}$.

各条件下で溶出中あるいは溶出後の試料の外観を観察し た. 完全に溶出終了後, 純水で十分洗浄し, 約 $120^{\circ} \mathrm{C}$ で一晚乾燥した。をの後, 特性測定と組成分析を行った。

\section{3 表面積, 細孔容積測定}

調製した多孔質ガラスの表面積 $S\left(\mathrm{~m}^{2} / \mathrm{g}\right)$ は $\mathrm{N}_{2}$ 吸着

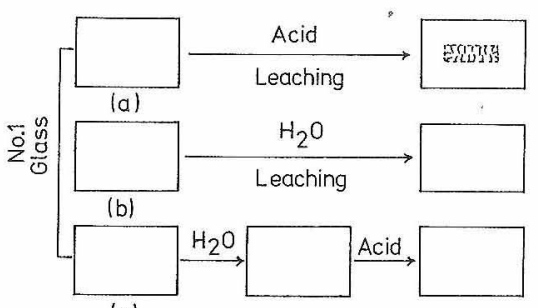

(c)

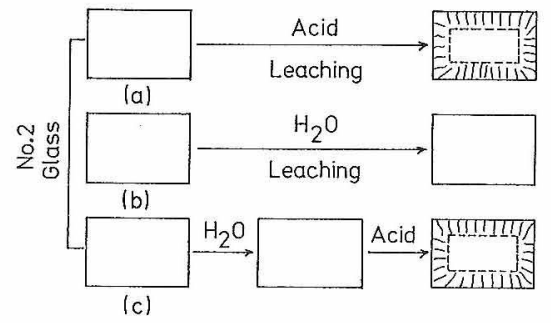

Fig. 2. Schematic representation of cracking of porous glasses under various leaching conditions.

による BET一点法で測定した。また細孔容樍 $V_{\mathrm{p}}(\mathrm{cc} / \mathrm{g})$ は水中に浸漬した試料の乾燥前後の重量を测定すること によって求めた。

\section{3. 結 果}

\section{1 割れの発生}

No. 1 およびNo.2ガラスの（a）条件における溶出 過程の外観を図 1 に，また，3種類の条件下での溶出状 態を模式的に図 2 に示す（a）条件で溶出した場合, No. 1 ガラスでは溶出の後期に未溶出層に，No. 2 ガラ スでは溶出のごく初期から溶出層に割れが生じた。とこ ろが，（b）条件の熱水溶出では，両ガラスとも割れは 生じなかった。熱水溶出後, 再び（c）条件の酸溶出を 行うと，No.1ガラスでは（b) 条件と同様に割机は生 
Table 2. Properties and chemical compositions (wt \%) of porous glasses.

\begin{tabular}{c|c|c|c|cccc}
\hline Glass & Leaching & $V_{p}$ & S & \multicolumn{4}{|c}{ Chemical compositions (wt\%) } \\
No. & condition & $(\mathrm{cc} / \mathrm{g})$ & $\left(\mathrm{m}^{2} / \mathrm{g}\right)$ & $\mathrm{Si02}$ & $\mathrm{A} 1203$ & $\mathrm{~B} 203$ & Na20 \\
\hline 1 & a & 0.634 & 290 & 95.1 & 0.20 & 4.53 & 0.14 \\
& b & 0.505 & 210 & 88.9 & 3.52 & 4.66 & 2.90 \\
& c & 0.694 & 200 & 96.3 & 0.28 & 3.39 & 0.04 \\
\hline 2 & a & 0.674 & 334 & 95.6 & 0.22 & 4.12 & 0.06 \\
& b & 0.566 & 226 & 86.3 & 6.76 & 2.25 & 4.68 \\
& c & 0.727 & 206 & 97.9 & 0.17 & 1.80 & 0.07 \\
\hline
\end{tabular}

じないが，No.2ガラスでは，再び溶出がはじまったか の上うな溶出境界線が現れ, 溶出層に割れが生じた。

\section{2 多孔質ガラスの特性と組成}

得られた多孔質ガラスの表面積, 細孔容積及び分析組 成を表 2 に示す。これより, 表面積, 細孔容積について は，溶出条件が同じであれば，両ガラス間に大きな差は ない。（b）条件の熱水溶出の場合，（a）条件の溶出に 比較して, 細孔容積が約 $0.1 \mathrm{cc} / \mathrm{g}$, 表面積が約 100 $\mathrm{m}^{2} / \mathrm{g}$ 小さい。熱水溶出後, 再び $(\mathrm{c})$ 条件の酸溶出を 行う之, (a ) 条件の場合上り, 表面積が約 $110 \mathrm{~m}^{2} / \mathrm{g}$ 小 さく, 細孔容積は約 $0.05 \mathrm{cc} / \mathrm{g}$ 大きい. また, 熱水溶出 の場合と比較すると, 表面積の差は小さいが, 細孔容積 は約 $0.15 \sim 0.20 \mathrm{cc} / \mathrm{g}$ 大きい.

一方, 溶出後の各試料の組成は, 溶出条件によって異 なり，特に熱水溶出したものには， $\mathrm{Al}_{2} \mathrm{O}_{3}$ と $\mathrm{Na}_{2} \mathrm{O}$ が多 量に残留していた. No.1 ガラスでは, $\mathrm{B}_{2} \mathrm{O}_{3}$ の方が $\mathrm{Na}_{2} \mathrm{O}$ 上り多く残っているのに対し，No. 2 ガラスでは その逆である.しかし, 熱水溶出後再び酸溶出すると, 残留していた $\mathrm{Al}_{2} \mathrm{O}_{3}$ と $\mathrm{Na}_{2} \mathrm{O}$ はほとんど溶出された。

\section{4. 考 察}

\section{1 割れとひずみについて}

酸溶出を行った試料に観察された 2 種類の典型的な割 れについて, 試料の伸縮に伴うひずみ発生の観点から考 察する. ガラス試料が基本的に引つ張り応力に弱く, 更 に多孔質ガラス層 (溶出層) が元のガラス層 (未溶出層) より弱いことから, 割れが発生した層には引っ張り応力 が働いていたものと考えられる。このような引っ張り応 力が働くのは, 溶出時にガラス試料が伸縮するためであ り ${ }^{21}$, 溶出されていないガラス層は伸縮しないと考えて よいから, 結局, 溶出層 (多孔質ガラス層) が膨張ある いは収縮していることになる。この様子を模式的に図 3 に示す。

本実験での酸溶出では，No.1 ガラスの場合，図 3(A) のように溶出層が膨張して未溶出層に引つ張り忘力が発 生し, No.2 ガラスの場合, 図 3(B) のように溶出層が 収縮して溶出層に引つ張り応力が発生したと考えられ る。特に, 溶出層は強度が小さく, 小さな引っ張り応力

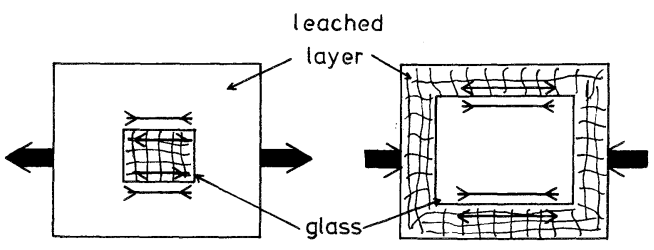

(A) Swelling

(B) Shrinking

Fig. 3. Schematic representation of stress built-up and cracking of porous glasses during leaching. Large arrow; Swelling or shrinkage.

Small arrow; Compressive or tensile stress.

が発生しても割れやすいために, 溶出のごく初期に溶出 層に割れが生じる可能性が強い。一方，未溶出層に引っ 張り応力が生じる場合には，応力の程度にもよるが前記 のものほど簡単には割れず，また，割れる場合も溶出の 後期におこるものと考えられる.

\section{2 伸縮の原因について}

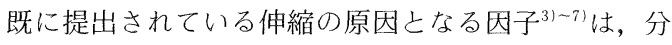
相後の 2 相の組成に深く関係しており，ここでは，溶出 時の試料の伸縮とガラス組成との関係について考える.

一般に, $\mathrm{SiO}_{2}-\mathrm{B}_{2} \mathrm{O}_{3}-\mathrm{Na}_{2} \mathrm{O}$ 系ガラスに $\mathrm{Al}_{2} \mathrm{O}_{3}$ を導入す ると, 分相温度が低下し分相領域が狭くなることが知ら れている9。このことは, $\mathrm{SiO}_{2}$ リッチ相がより多くの $\mathrm{Na}_{2} \mathrm{O}$ や $\mathrm{B}_{2} \mathrm{O}_{3}$ を含むようになり, 一方, $\mathrm{Na}_{2} \mathrm{O}-\mathrm{B}_{2} \mathrm{O}_{3}$ リッ チ相もより多くの $\mathrm{SiO}_{2}$ を含むようになることを意味し ている. $\mathrm{Al}_{2} \mathrm{O}_{3}$ の導入量が増せば，この傾向も増す。こ のようなガラスを酸溶出した場合, 細孔中の $\mathrm{SiO}_{2}$ ゲル の残留量が増して水和による膨張量が大きくなるが4), $\mathrm{SiO}_{2}$ リッチ相からの $\mathrm{Na}_{2} \mathrm{O}$ の抽出による収縮量も増加 し, 全体として, $\mathrm{Al}_{2} \mathrm{O}_{3}$ を含まないものより膨張量は小 さくなる2!

本研究において, 2 種類のガラスを酸溶出すると, No. 1 ガラスは膨張し，No.2 ガラスは収縮することが， 割れの発生状態から明らかである。このことは，No.1 ガラスにおいて $\mathrm{SiO}_{2}$ ゲルの水和という因子が支配的で あり, No. 2 ガラスでは $\mathrm{SiO}_{2}$ リッチ相からの $\mathrm{Na}_{2} \mathrm{O}$ の抽 出という因子が支配的であったことを示すものである。 ところが, 熱水溶出するといずれのガラスも割れが生じ なかった。熱水溶出後の試料之酸溶出後のそれを比較す ると, 前者の表面積亡細孔容積は後者より小さい。これ は, 細孔中に残留している $\mathrm{SiO}_{2}$ ゲルが少ないことを示 していると考えられる。また, 熱水溶出後の試料には相 当量の $\mathrm{Na}_{2} \mathrm{O}$ が残留し(表2), 特に No.2 ガラスには約 $4.7 \%$ もの $\mathrm{Na}_{2} \mathrm{O}$ が残留していた。このことは $\mathrm{SiO}_{2} リ ッ$ チ相中からの $\mathrm{Na}_{2} \mathrm{O}$ の抽出量が少なかったことを示して いる.したがって, 熱水溶出では膨張の原因となる $\mathrm{SiO}_{2}$ ゲルの残留量が少なく, $\mathrm{SiO}_{2}$ リッチ相からの $\mathrm{Na}_{2} \mathrm{O}$ の抽出量も少ないために割れなかったのであり, 当初の仮定が正しいと判断できる. 
さて，熱水溶出すれば伸縮に寄与する因子が相当抑制 され，いずれのガラスにも割れが生じなかったが，これ らのガラスを再び酸溶出すると, No. 1 ガラスは割れが 生じなかったが, No. 2 ガラスでは再び溶出層に割れが 観察された。これは，No. 2 ガラスでは，収縮因子が先 の熱水溶出で完全に除去されていないためである。すな わち, No. 2 ガラスは熱水溶出後に残留する $\mathrm{Na}_{2} \mathrm{O}$ 量が 多く, これが, 酸溶出によって抽出されるとき, 溶出層 の収縮がおこるためと考えられる．事実，表 2 に示すよ うに，多量の $\mathrm{Na}_{2} \mathrm{O}$ がこの段階で抽出されている。

\section{5. 結 論}

多孔質ガラスの溶出中の割れに関して, 酸処理過程で 未溶出層のみあるいは溶出層のみに割れが発生するよう なガラス組成，熱処理条件及び溶出条件を選び，割れの 原因となる因子を検証した。

酸処理中の割れは, 試料が伸縮する際, 溶出層と未溶 出層の境界にひずみが発生し, 引つ張り応力がいずれか の層に働くためと考えられた。このような引っ張り応力 を減少あるいは消失させるためには， $\mathrm{SiO}_{2}$ リッチ相か らの $\mathrm{Na}_{2} \mathrm{O}$ の抽出がなく, かつ細孔中に $\mathrm{SiO}_{2}$ ゲルが残 留しないように溶出することが重要であり, 熱水溶出は
このような条件を満たすことが明らかになった。しかし， 熱水溶出により収縮の原因となる $\mathrm{SiO}_{2}$ リッチ相中の $\mathrm{Na}_{2} \mathrm{O}$ が抽出されていないがラスでは，引き続き酸溶出 すると $\mathrm{Na}_{2} \mathrm{O}$ が溶出し, 溶出層に再び割れが生じること が分かった。

謝 辞 本研究は, 一部, Grant No.AFOSR-80-0059 of the U.S. Air Force の援助で行われた。ここに謝意を表します。

\section{文献}

1) H. P. Hood and M.E. Nordberg, U.S. Patents 2, 215, 039 (1940).

2）江口清久, 植月倫夫, 垂水修二, 窯協, 87, 558-64 (1979),

3) M. B. Volf, “Technical Glasses”, Pitman \& Sons Ltd., London (1961) pp. 176-209.

4) T. Takamori and M. Tomozawa, J. Am. Ceram. Soc., 65, C 127-28 (1982).

5) M. G. Drexhage and P. K. Gupta, ibid., 63, 196-201 (1980).

6) G. W. Scherer and M. G. Drexhage, ibid., 68, 419-26 (1985).

7）江口清久，大阪工業技術試験所報告，No.355（1980） pp. 25-26.

8) J. J. Hammel and T. Allersma, U.S. Patents 3, 843, 341 (1974).

9) K. Nakagawa and T. Izumitani, Phys. Chem. Glasses, 13, 85-90 (1972). 